\title{
Heritability Estimation and Non-Genetic Factors Affecting Production Traits of Indonesian Ongole Cross
}

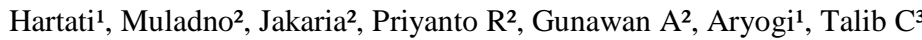 \\ ${ }^{1}$ Beef Cattle Research Station, Jl. Pahlawan No. 2 Grati Pasuruan \\ ${ }^{2}$ Department of Animal Production and Technology, Faculty of Animal Science, Bogor Agricultural University \\ ${ }^{3}$ Indonesian Center for Animal Research and Development. Jln Raya Pajajaran Kav. E59 Bogor \\ E-mail: hartati06@yahoo.com
}

(received 30-07-2015; revised 26-08-2015; accepted 14-09-2015)

\begin{abstract}
ABSTRAK
Hartati, Muladno, Jakaria, Priyanto R, Gunawan A, Aryogi, Talib C. 2015. Estimasi nilai heritabilitas dan faktor non-genetik yang mempengaruhi sifat-sifat produksi sapi PO. JITV 20(3): 168-174. DOI: http://dx.doi.org/10.14334/jitv.v20i3.1183

Data produktivitas dari 560 ekor sapi PO telah dikoleksi selama 9 tahun pengamatan dari 2004 sampai 2013 untuk mengkaji estimasi nilai heritabilitas dan pengaruh non-genetik terhadap sifat produksi sapi PO dari lahir sampai umur satu tahun. Estimasi nilai heritabilitas dilakukan dengan analisis variansi menggunakan data saudara tiri sebapak (Paternal Halfsib Correlation). Pemisahan komponen ragam untuk menduga nilai heritabilitas dilakukan dengan analisis sidik ragam Rancangan Acak Lengkap pola searah. Sedangkan pengaruh non-genetik (jenis kelamin, tahun, paritas, musim, generasi dan tipe lahir) dianalisis menggunakan Generalized Linier Model (GLM). Hasil penelitian menunjukkan bahwa jenis kelamin dan tahun berpengaruh nyata $(\mathrm{P}<0,05)$ pada sifat-sifat produksi yang meliputi bobot lahir, bobot sapih dan bobot setahun, sedangkan tipe lahir hanya berpengaruh nyata pada bobot lahir saja. Paritas, musim dan generasi menunjukkan pengaruh yang tidak nyata terhadap ketiga variabel produksi tersebut. Estimasi nilai heritabilitas bobot lahir, bobot sapih dan bobot setahun berturut-turut $0,28 \pm 0,12$; $0,47 \pm 0,15$ dan $0,63 \pm 0,17$. Nilai heritabilitas tertinggi diperoleh pada bobot setahun, hal ini berarti bahwa bobot setahun efektif untuk digunakan sebagai kriteria seleksi dalam meningkatkan perbaikan genetik sapi PO.
\end{abstract}

Kata Kunci: Genetik, Non-Genetik, Produksi, Sapi PO

\section{ABSTRACT}

Hartati, Muladno, Jakaria, Priyanto R, Gunawan A, Aryogi, Talib C. 2015. Heritability estimation and non-genetic factors affecting production traits of Indonesian Ongole cross. JITV 20(3): 168-174. DOI: http://dx.doi.org/10.14334/jitv.v20i3.1183

Productivity data from 560 head of PO cattle have been collected for 9 years from 2004 until 2013 for evaluating heritability estimation and non-genetic factors affecting production traits of Indonesian Ongole cross from birth to yearling old. Heritability estimation were analyzed using varians analysis with data of paternal halfsib correlation. Varians component for to estimate of heritability value were analyzed using completely randomized design one - way classification. While a general linear model was used to analyze non-genetic factors (sex, year, parity, season, generation and type of births). The results showed that sex of calves and year of births had significant differences $(\mathrm{P}<0.05)$ for all production traits such as weight at birth, weaning and yearling, while the type of birth only presented a significant difference on birth weight. Parity, season and generation exhibited nonsignificantly effect on those production traits. Estimation of heritability on birth weight, weaning weight and yearling weight were $0.28 \pm 0.12,0.47 \pm 0.15$ and $0.63 \pm 0.17$ respectively. The highest heritability values obtained in yearling weight, this means that yearling weight will be effective as selection criteria to improve the genetic of PO cattle.

Key Words: Genetic, Non-Genetic, Production, PO Cattle

\section{INTRODUCTION}

PO cattle is one of the local cattle which is formed from the cross between Ongole sires on the island of Sumba (SO) with dam in Java that occurred decades ago (KepMenTan 2012). PO cattle is known to have a high diversity (Hartati et al. 2010), also have high adaptability and able to survive in conditions of tropical regions (Astuti 2004). These facts indicate performance of good productivity as good as other local cattle.
However, nowadays the existence of PO cattle has been widely reported to be degraded and decreased in genetic quality. Since the introduction of technology Artificial Insemination (AI) in the era of the 70s, almost 95\% PO cows in farmer have been crossed with Bos taurus breeds. This crossing was initially thought to improve the productivity of local cattle, began to lose direction and purpose. Mostly the result of crosses actually used as broodstock and backcross to Bos taurus again, to increase Bos taurus genetic composition, it affected adaptability and decrease productivity as well 
as contamination of the genetic quality of PO cattle. Currently, it is difficult to find PO cattle that have a good performance, even decline in productivity not only in weight and dimension of body size but also visible to reproduction aspects.

Various efforts have been done to improve the productivity of PO cow, one of which is through the selection program to produce quality cattle. Selection in principle is choosing animals that are genetically good quality to be used as a parent in the next generation, but in the implementation of this program is not provide optimal results. Selection conventionally takes a long time and a large population so that the selection program could only be applied to breeding livestock of government such as the Beef Cattle Research Station that does have the duties and functions to produce quality cattle, whereas in farmer which has the most population of PO cattle, selection programme can not be applied optimally because it is not supported by the data of production so the genetic potential are difficult to evaluate.

Beef Cattle Research Station as one of the technical management unit of Indonesian Agency for agricultural Research and Development Ministry of Agriculture has conducted breeding of PO cattle since 2004 until now, but the evaluation of genetic potential has not been done. Several result of studies have been reported, according to Adinata (2013) breeding value estimation for birth weight of PO cattle in Management Unit of Seed Source, heritability and repeatability were $0.686 \pm 0.525$ and $0.805 \pm 0.041$, whereas Prihandini et al. (2012) reported sire selection based on breeding values for weight 205 days and 365 days.

Evaluation of the genetic potential of livestock can be measured based on production and reproduction ability. The quantitative data of biological potency like production and reproduction phenotipic was inseparable from environmental influences where livestock were kept (Astuti 2004). Therefore, in addition to study about the effect of genetic such as heritability and breeding value estimation, the study of non-genetic influence was also done to eliminate biases caused by them such as the effect of sex, year, season, parity, generation and the type of birth. This study aimed to evaluate heritability estimation and non-genetic factors affecting production traits of PO cattle.

\section{MATERIALS AND METHODS}

\section{Sources of data}

In this study data used was records of PO cattle at Beef Cattle Research Station in Grati, Pasuruan, East Java for 9 years from 2004 to 2013. Productivity data from 560 head of PO calves have been collected from 253 head dams and 53 head sires. Data of individual animals that were available include calf, dam and sire number, date of birth, sex, parity, generation, type of birth, season and year of birth, weight at birth, weaning and yearling. Birth weight as the weight of animal in 24 hour after birth, weaning weight and yearling weight were obtained by calculating weight of animals from recorded data with the weight closest to the age of 205 days and 365 days respectively. Formulas used for calculating were as follows:

$$
\begin{aligned}
& \text { WW }(205)=\frac{(\mathrm{AWW}-\mathrm{B})}{\mathrm{AA}} \times 205+\mathrm{BW} \\
& \mathrm{YW}(365)=\frac{(\mathrm{AYW}-\mathrm{Weight} 205)}{\mathrm{AA}-205} \times 160+\text { Weight } 205
\end{aligned}
$$

where:

AWW = Actual weaning weight

BW = Birth weight

AYW = Actual yearling weight

$\mathrm{AA}=$ Actual age

Feed ingredients used refers to the concept of Low External Input Sustainable Agriculture (LEISA) that utilize agricultural wastes were available throughout the season such as rice straw dry had ad libitum $(+600 \mathrm{~kg} / 7$ days $/ 20$ head), concentrate feed $8 \mathrm{~kg} / \mathrm{head} /$ day which were mix of tumpi, oil palm, rind coffee, bran quality 2 ,

\begin{tabular}{|c|c|c|c|}
\hline \multirow{2}{*}{ Physiological status } & \multicolumn{3}{|c|}{ Nutritional content (DM) } \\
\hline & $\mathrm{CP}(\%)$ & TDN (\%) & $\mathrm{CF}(\%)$ \\
\hline Dry periode & $8-9$ & $55-57$ & $20-22$ \\
\hline Mating, pregnant - weaning & $9-10$ & $57-60$ & $18-20$ \\
\hline Weaning calves - 24 month & $9-10$ & $58-60$ & $20-22$ \\
\hline Sire candidate ( $>18$ month) and sire & $10-12$ & $58-60$ & $20-22$ \\
\hline
\end{tabular}
limestone and salt. Nutrien content of feed is presented in Table 1.

Table 1. The nutritional content of feed PO cattle appropriate physiological status 


\section{Data analyses}

\section{Heritability value}

Heritability estimation was calculated by analysis of variance using paternal halfsib correlations, where each bull mated with some cow and each cow has one progeny. Separation of variance components to estimate the heritability performed by analysis of variance Completely Randomized Design One-Way Classification with a mathematical model as follows (Becker 1992; Hardjosubroto 1994):

$$
\mathrm{Yik}=\mu+\alpha \mathrm{i}+\mathrm{eik}
$$

where:

$\mu=$ Common mean

$\alpha \mathrm{i}=$ Effect of the $\mathrm{i}^{\mathrm{th}}$ sire

eik = Uncontrolled environmental deviations associated with each record

Heritability value is estimated from sire variance components, according to Becker (1992) as follows:

$$
\begin{aligned}
& \mathrm{h}^{2}=4 \delta^{2} \mathrm{~s} /\left(\delta^{2} \mathrm{~s}+\delta^{2} \mathrm{w}\right) \\
& \mathrm{SE}=4 \sqrt{\frac{2(1-\mathrm{t})^{2}[1+(\mathrm{k}-1)(\mathrm{t})]^{2}}{\mathrm{k}(\mathrm{k}-1)(\mathrm{s}-1)}}
\end{aligned}
$$

where:

$\mathrm{h}^{2}=$ Heritability

$\delta^{2} \mathrm{~s}=$ Sire variance component

$\delta^{2} \mathrm{~W}=$ Within progeny variance component

$\mathrm{k}=$ Number of progeny per sire

$\mathrm{S}=$ Number of sires

$\mathrm{t}=\delta^{2} \mathrm{~s} /\left(\delta^{2} \mathrm{~s}+\delta^{2} \mathrm{w}\right)$

\section{Non-genetic influences}

Data were analyzed to evaluate the effect of sex, year, season, parity, generation, and the type of birth on body weight at those certain ages. Seasons of birth in the year were divided into two seasons, namely dry (April-September) and rainy season (October to March). To determine the influence of non-genetic factors, data were analyzed using General Linear Model (GLM) (Steel \& Torrie 1980) with the mathematical model as follow:

$$
\mathrm{Y}_{\mathrm{ijklmn}}=\mu+\mathrm{r}_{\mathrm{i}}+\mathrm{s}_{\mathrm{j}}+\mathrm{p}_{\mathrm{k}}+\mathrm{q}_{\mathrm{l}}+\mathrm{n}_{\mathrm{m}}+\mathrm{m}_{\mathrm{n}}+\mathrm{e}_{\mathrm{ijklmn}}
$$

where:

$\mathrm{Y}_{\mathrm{ijklmn}}=$ Weight at birth, weaning, yearling and 2 years

$\mu \quad=$ Overall mean

$r_{i} \quad=$ the effect of $i^{\text {th }}$ years at birth (year 2003 to 2013)

$\mathrm{s}_{\mathrm{j}} \quad=$ the effect of $\mathrm{j}^{\mathrm{th}}$ sex of calves (male, female)

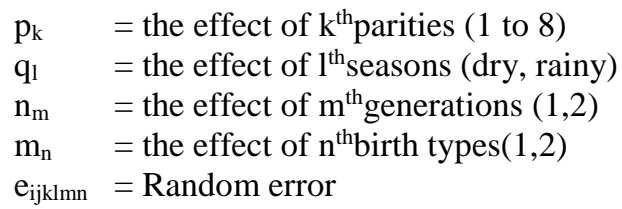

RESULTS AND DISCUSSION

\section{Performance production of PO cattle}

Statistical analysis of environmental influences on body weight of PO cattle and heritability estimation of birth weight, weaning weight and yearling weight are presented in Table 2 and 3.

\section{Birth weight}

Statistical analysis showed that sex, year and birth type significantly affected $(\mathrm{P}<0.05)$ birth weight in $\mathrm{PO}$ cattle, whereas parity, season and generation showed no significant effect. Birth weight of male calves was higher than that of the females $25.3+3.4$ and $23.9+3.2$ respectively (Table 2), whereas the overall average of birth weight of PO cattle was $24.6+3.4 \mathrm{~kg}$. Birth weight in this research was lower compared to the results of Adinata (2013) who obtain birth weight PO cattle in Seed Resources Management Unit (UPBS) of $25.93 \pm 3.97 \mathrm{~kg}$, but higher than the result reported by Supartini et al. (2014) birth weight PO cattle aged 4 days at the farmer of Tambakrejo subdistrict, Bojonegoro amounted to $11.07+3.92 \mathrm{~kg}$.

Effect of year on birth weight in this study was greatly fluctuate from year to year with the trend in 2010> 2013> 2004 (Table 2). The highest birth weight was obtained in 2013 with the average weight of $25.8+$ $3.3 \mathrm{~kg}$, whereas the lowest birth weight obtained in 2004 with an average of $22.3+3.0 \mathrm{~kg}$, but in general the birth weight of 2004 to 2013 showed an increasing trend.

Birth type affected significantly $(\mathrm{P}<0.05)$ on birth weight, where calves form single birth had greater birth weight than those from twin birth. Difference of individual birth weight between twin and single birth is up to $7 \mathrm{~kg}$ or approximately $28.3 \%$. Field observation and recording data analysis for 9 years in Beef Cattle Research Station shows that the probability of twinning in PO cattle around $1.4 \%$. This result was in line with Komisarek \& Dorynek (2002) that natural percentage of twin birth in beef cattle was less than $1 \%$. Previous study reported that twinning birth in dairy cattle were between $1 \%$ and $4 \%$. The probability of twinning could increase in line with the increasing of dam age where the rate of multiple births increased during the period of the 10 year age of the dams and and the greatest rise of 
Table 2. Mean along with their standard deviation (SD) for birth, weaning and yearling weight $(\mathrm{kg})$

\begin{tabular}{|c|c|c|c|}
\hline \multirow{2}{*}{ Performans of calves } & \multicolumn{3}{|c|}{ Production Traits } \\
\hline & Birth weight (n) & Weaning weight $(\mathrm{n})$ & Yearling weight (n) \\
\hline \multicolumn{4}{|l|}{ Sex } \\
\hline Male & $25.3 \pm 3.4(267)^{\mathrm{a} *)}$ & $108.5 \pm 28.6(264)^{\mathrm{a}}$ & $157.1 \pm 40.6(255)^{\mathrm{a}}$ \\
\hline Female & $23.9 \pm 3.2(293)^{b}$ & $100.9 \pm 24.7(291)^{b}$ & $147.3 \pm 38.1(284)^{b}$ \\
\hline \multicolumn{4}{|l|}{ Years } \\
\hline 2004 & $22.3 \pm 3.0(29)^{\mathrm{a}}$ & $92.9 \pm 15.9(29)^{\mathrm{a}}$ & $119.7 \pm 25.0(29)^{\mathrm{a}}$ \\
\hline 2005 & $22.8 \pm 3.4(32)^{\mathrm{a}}$ & $96.4 \pm 21.5(32)^{\mathrm{a}}$ & $135.6 \pm 25.4(32)^{\mathrm{a}}$ \\
\hline 2006 & $24.6 \pm 4.3(23)^{\mathrm{a}}$ & $77.6 \pm 21.6(23)^{\mathrm{a}}$ & $111.9 \pm 34.8(23)^{\mathrm{a}}$ \\
\hline 2008 & $25.6 \pm 3.4(44)^{\mathrm{ab}}$ & $106.6 \pm 27.1(43)^{\mathrm{ab}}$ & $147.7 \pm 38.8(42)^{\mathrm{ab}}$ \\
\hline 2009 & $25.4 \pm 3.1(71)^{\mathrm{ab}}$ & $97.5 \pm 19.4(71)^{\mathrm{ab}}$ & $152.4 \underline{+32.0}(71)^{\mathrm{ab}}$ \\
\hline 2010 & $24.0 \pm 3.2(100)^{\mathrm{a}}$ & $108.4 \pm 26.6(100)^{\mathrm{ab}}$ & $158.8 \pm 37.4(99)^{\mathrm{b}}$ \\
\hline 2011 & $24.3 \pm 3.7(65)^{\mathrm{a}}$ & $94.3 \pm 20.7(64)^{\mathrm{b}}$ & $140.8 \pm 29.7(63)^{\mathrm{ab}}$ \\
\hline 2012 & $24.3 \pm 2.8(98)^{\mathrm{a}}$ & $100.6 \pm 25.8(98)^{\mathrm{ab}}$ & $150.6 \pm 33.7(98)^{\mathrm{ab}}$ \\
\hline 2013 & $25.8 \pm 3.3(98)^{b}$ & $127.9 \pm 25.5(96)^{\mathrm{b}}$ & $183.8+45.8(83)^{\mathrm{c}}$ \\
\hline \multicolumn{4}{|l|}{ Parity } \\
\hline 1 & $23.9 \pm 3.4(226)^{\mathrm{a}}$ & $99.7 \pm 23.8(226)^{\mathrm{a}}$ & $146.0 \pm 34.9(220)^{\mathrm{a}}$ \\
\hline 2 & $24.9 \pm 3.1(142)^{\mathrm{a}}$ & $105.2 \pm 29.7(140)^{\mathrm{a}}$ & $153.3 \pm 43.1(135)^{\mathrm{a}}$ \\
\hline 3 & $25.1 \pm 3.6(90)^{\mathrm{a}}$ & $106.5 \pm 28.1(89)^{\mathrm{a}}$ & $150.6 \pm 43.4(87)^{\mathrm{a}}$ \\
\hline 4 & $25.1 \pm 3.3(57)^{\mathrm{a}}$ & $115.2 \pm 27.3(56)^{\mathrm{a}}$ & $169.7 \pm 42.4(54)^{\mathrm{a}}$ \\
\hline 5 & $24.7 \pm 3.7(29)^{\mathrm{a}}$ & $111.8 \pm 24.1(29)^{\mathrm{a}}$ & $166.3 \pm 32.0(29)^{\mathrm{a}}$ \\
\hline 6 & $26.1 \pm 2.7(16)^{\mathrm{a}}$ & $104.6 \pm 27.1(15)^{\mathrm{a}}$ & $142.3 \pm 26.6(14)^{\mathrm{a}}$ \\
\hline \multicolumn{4}{|l|}{ Seasons } \\
\hline Rainy & $24.5 \pm 3.0(195)^{\mathrm{a}}$ & $105.4 \pm 27.1(192)^{\mathrm{a}}$ & $152.3 \pm 39.4(179)^{\mathrm{a}}$ \\
\hline Dry & $24.6 \pm 3.6(365)^{\mathrm{a}}$ & $104.0 \pm 26.8(363)^{\mathrm{a}}$ & $151.8 \pm 39.7(360)^{\mathrm{a}}$ \\
\hline \multicolumn{4}{|l|}{ Generation } \\
\hline 1 & $24.7 \pm 3.5(393)^{\mathrm{a}}$ & $103.5 \pm 26.3(389)^{\mathrm{a}}$ & $149.7 \pm 39.1(380)^{\mathrm{a}}$ \\
\hline 2 & $24.4 \pm 3.1(167)^{\mathrm{a}}$ & $106.8 \pm 28.2(166)^{\mathrm{a}}$ & $157.2 \pm 40.2(159)^{\mathrm{a}}$ \\
\hline \multicolumn{4}{|l|}{ Birth Type } \\
\hline 1 & $24.7 \pm 3.3(552)^{\mathrm{a}}$ & $104.7 \pm 26.8(547)^{\mathrm{a}}$ & $152.2 \pm 39.4(531)^{\mathrm{a}}$ \\
\hline 2 & $17.7 \pm 4.1(8)^{\mathrm{b}}$ & $88.6 \pm 31.1(8)^{\mathrm{a}}$ & $135.3 \pm 47.8(8)^{\mathrm{a}}$ \\
\hline Total Average & $24.6 \pm 3.4(560)$ & $104.5 \pm 26.9(555)$ & $151.9 \pm 39.6(539)$ \\
\hline
\end{tabular}

*) Different of letters in the same section within column shows significantly different $(\mathrm{P}<0.05)$

Table 3. Heritability estimation of body weight of PO cattle

\begin{tabular}{lccccc}
\hline \hline Traits & $\mathrm{n}$ & $\mathrm{h}^{2} \pm \mathrm{SE}$ & $\mathrm{Vs}$ & $\mathrm{Ve}$ & $\mathrm{Vp}$ \\
\hline Birth Weight & 560 & $0.28 \pm 0.12$ & 3.148 & 10.6 & 11.387 \\
Weaning Weight & 555 & $0.47 \pm 0.15$ & 338 & 640 & 724.50 \\
Yearling Weight & 539 & $0.63 \pm 0.17$ & 997.47 & 1325 & 1574.367 \\
\hline
\end{tabular}

$\mathrm{n}=$ Number of calves; $\mathrm{h}^{2}=$ Heritability; $\mathrm{Vs}=$ Sire variance $\mathrm{Ve}=$ Environment variance; $\mathrm{Vp}=$ Phenotypic variance 
twinning occurred in first and second parity (Berry et al. 1994; Cady \& Van Vleck 1978; Kinsel et al. 1998; Nielen et al. 1989; Ryan \& Boland 1991), whereas in this study twinning occured in first, third and fifth parity.

Result of heritability estimation for birth weight of PO cattle was $0.28+0.12$ (Table 3 ). The heritability in this study was lower than heritability of other local cattle. Gunawan et al. (2011) reported heritability of birth weight for Bali cattle amounted $0.09+0.99$. Whereas Adinata (2013) reported heritability of birth weight for PO cattle in UPBS groups was higher namely $0.686 \pm 0.525$. Heritability of birth weight in this study was similar to heritability of birth weight for Zebu breed reported by Albuquerque \& Meyer (2001) 0.28 . Boligon et al. (2009) reported that heritability for birth weight of Nellore cattle (Bos indicus) was 0.25. Araujo et al. (2014) reported estimation of heritability for birth weight of Nellore Cattle in The Midwest region of Brazil was $0.37 \pm 0.02$. This is very relevant considering that PO and Nellore cattle are two breeds that have a kinship. Historically, Nellore cattle was Ongole breed imported from India and developed in Brazil and PO cattle was a crossbred between bull of Ongole from India in the Sumba island (namely SO) with Java cows. Generally, the value of heritability on birth weight in this study was quite moderate and within the range of published values by Hardjosubroto (1994) $0.2-0.58$, these result show that the correlation of phenotypic variances and genetic variances is quite moderate so the selection based on the phenotypic of the individual birth weight to be quite effective. Lasley (1978) stated that selection on birth weight can be done to improve genetic quality weaning weight trait, yearling and weaning daily gain due to the high correlation of genetic variances in these traits.

\section{Weaning weight}

The overall average of weaning weight of PO cattle was $104.5 \pm 26.9 \mathrm{~kg}$. Weaning weight in this research was lower than that reported by Aryogi et al. (2006) that weaning weight of PO cattle at the farmer in East Java was $109 \mathrm{~kg}$. Statistical analysis of the environmental influence showed that sex and year were significant $(\mathrm{P}<0.05)$ on weaning weight of $\mathrm{PO}$ cattle (Table 2). Maylinda (2010) stated that weaning weight was influenced by many environmental factors, especially the management and maintenance of the genetic component of the parental (maternal genetic effects) such as the production of milk and breast feeding behavior that ultimately affected the performance of individuals. It is very relevant to this study, in which the male calves have greater $(108.5 \pm 28.6 \mathrm{~kg})$ weight than the females $(100.9 \pm 24.7$ $\mathrm{kg}$ ). This is likely due to male calves have a greater ability to stimulate the production of mother's milk during suckling, so that the male consumes more nutrients than the female. Thus weaning weight can also be used as a criterion in selecting the dam that has good mothering abilities.

Effect of year on weaning weight in this study was greatly fluctuate from year to year with the trend in 2010> 2013> 2006 (Table 2). The highest weaning weight was obtained in 2013 with average of $127.9 \pm 25.5 \mathrm{~kg}$, whereas the lowest weaning weight was obtained in 2006 an average of $77.6 \pm 21.6 \mathrm{~kg}$.

Heritability estimation for weaning weight of PO cattle was $0.47 \pm 0.15$ (Table 3 ). Heritability value in this study was higher than heritability commonly found in offspring of Ongole breed in some other countries. Silva et al. (2013) reported heritability of Ongole breed developed in Brazil or known as Nellore cattle was 0.13. While Araujo et al. (2014) found heritability was 0.36 . Heritability can varies higher or lower from one study to other studies, it is likely influenced by the ability of the environment that will reduce the influence of pure genetic elements in cattle. But, generally heritability in this study was high category due more than 0.4 (Noor 2010). The high value of heritability of weaning weight showed that the selection on the basis of performance of the individual will be more effective to increase daily gain in weaning weight that indicates these traits can increase the response selection.

\section{Yearling weight}

The overall average of yearling weight of PO cattle was $151.9+39.6$ (Table 2), lower than yearling weight the result reported by Aryogi et al. (2006) $166.4 \mathrm{~kg}$. Statistical analysis of the environmental influences showed that sex and year were significant $(\mathrm{P}<0.05)$ on yearling weight of PO cattle (Table 2). Result showed that the average of yearling weight of male PO cattle was higher than female: $157.1+40.6$ dan $147.3+38.1$, respectively. The difference of this weight might be attributed to different physiological processes in both sexes. Dadi et al. (2008) stated that sex had a highly significant influence on post weaning live weight and growth rate in Brahman cattle, differences in growth rate increased with age implying that sex effects are more pronounced with age after puberty. The result of this study describing that the influence of sex on live weight difference increased with age from $7.6 \mathrm{~kg}$ at weaning weight of age to $9,8 \mathrm{~kg}$ at yearling weight.

Effect of year on yearling weight in this study greatly fluctuate from year to year (Table 2). The highest yearling weight was obtained in 2013 with average of $183.8 \pm 45.8 \mathrm{~kg}$, whereas the lowest yearling weight was obtained in 2006 with an average of $111.9 \pm 34.8 \mathrm{~kg}$, but in general the yearling weight from 2004 to 2013 showed an increasing trend. 
Heritability values have been calculated for direct genetic effect of yearling weight was $0.63+0.17$ (Table 3 ). These results were higher than some of the Ongole breed heritability values previously reported in the literature. Silva et al. (2013) reported a heritability estimation of yearling weight of Nellore cattle using a mixed model of analysis of $0.03+0.02$. While Araujo et al. (2014) reported the estimated heritability of Nellore cattle in the Midwest region of Brazil $0.31+$ 0.01 . Santos et al. (2012) also reported a heritability values of 0.51 for yearling weight in which these values are lower than result of this study. The heritability value differences might be caused differences in the number of data structures, management and genetic data analysis methods. Clement et al. (2001) suggest that genetic variance was influenced by differences in the data number (structure) analyzed, the method of genetic analysis, the relationship among cattle herds and research time. The results of this study was an indication of good genetic progress for the growth traits of zebu cattle, especially in the tropical regions. Direct heritability estimation for body weight at evaluation of different age have medium and high value, it was indicating that additive genetic diversity sufficient to give response to selection. This result showed an indication that yearling weight can be used as an effective criterion for selection to improve growth rate in $\mathrm{PO}$ cattle.

\section{CONCLUSION}

Environment has significant influence (for sex and year) on: birth, weaning and yearling weight. Male calves have higher body weight than female calves, whereas performance of body weight of PO cattle was greatly fluctuate from year to year. Heritability estimation on birth, weaning and yearling weight were $0.28+0.12 ; 0.47+0.15$ and $0.63+0.17$ respectively. Heritability estimation on body weight of PO cattle was considered medium and high category. The highest heritability values obtained in yearling weight, this means that yearling weight will be effective as selection criteria to improve the genetic of PO cattle.

\section{ACKNOWLEDGEMENT}

The authors would like to extend gratitude to the Indonesian Agency for Agricultural Research and Development, Ministry of Agriculture through KKP3N activity in 2014 that has facilitated and funded this research activity. And our gratitude is also for Beef Cattle Research Station for full data and support, especially to friends who helped in the stable.

\section{REFERENCES}

Adinata Y. 2013. Estimasi nilai pemuliaan bobot lahir sapi Peranakan Ongole pada unit Pengelolaan Bibit Sumber di Loka Penelitian Sapi Potong. Purwantari ND, Saepulloh M, Iskandar S, Anggraeni A, Ginting SP, Priyanti A, Wiedosari E, Yulistiani D, Inounu I, Bahri S, Puastuti W, penyunting. Prosiding Seminar Nasional Teknologi Peternakan dan Veteriner. Medan (Indones): Pusat Penelitian dan Pengembangan Peternakan. hlm. 66-73.

Albuquerque LG, Meyer K. 2001. Etimates of direct and maternal genetic effects for weight from birth to 600 days of age in Nelore cattle. J Anim Breed Genet. 118:83-92.

Araújo CVD, Lôbo RB, Figueiredo LGG, Mousquer CJ, Laureano MMM, Bittencourt TCBDSCD, Araújo SI. 2014. Estimates of genetic parameters of growth traits of Nellore cattle in the Midwest Region of Brazil. Rev Bras Saúde Prod Anim Salvador. 15:846-853.

Aryogi, Prihandini PW, Wijono DB. 2006. Pola pembibitan sapi potong lokal Peranakan Ongole pada kondisi peternakan rakyat. Mathius IW, Sendow I, Purwantari, ND, Murdiati TB, Thalib A, Beriajaya, Suparyanto A, Prasetyo LH, Darmono, Wina E, penyunting. Prosiding Seminar Nasional Teknologi Peternakan dan Veteriner. Bogor (Indones): Pusat Penelitian dan Pengembangan Peternakan. hlm. 192-199.

Astuti. 2004. Potensi dan keragaman sumberdaya genetik sapi Peranakan Ongole (PO). Wartazoa. 14:98-106.

Becker WA. 1992. Manual of quantitative genetics. 5th ed. (USA): Academic Enterprises.

Berry SL, Ahmadi A, Thurmond MC. 1994. Periparturient disease on large, dry lot dairies: interrelationships of lactation, dystocia, calf number, calf mortality, and calf sex. J Dairy Sci. 77:379.

Boligon AA, Albuquerque LG, Mercadante MEZ, Lobo RB. 2009. Herdabilidades e correlações entre pesos do nascimento à idade adulta em rebanhos da raça Nelore. Braz J Anim Sci. 38:2320-2326.

Cady RA, Van Vleck LD. 1978. Factors affecting twinning and effects of twinning in Holstein dairy cattle. J Anim Sci. 46:950-956.

Clement V, Bibe B, Verrier E, Elsen JM, Manfredi E, Bouix J, Hanocq E. 2001. Simulation analysis to test the influence of model adequacy and data structure on the estimation of genetic parameters for traits with direct and maternal effects. Genet Sel Evol. 33:369-395.

Dadi H, Duguma G, Shelima B, Fayera T, Tadesse M, Woldu T, Tucho TA. 2008. Non-genetic factors influencing post-weaning growth and reproductive performances of Arsi-Bale goats. Livest Res Rural Develop. Article \#114. http://www.lrrd.org/lrrd20/7/dadi20114.htm.

Gunawan A, Jakaria. 2011. Genetic and non-genetics effect on birth, weaning and yearling weight of Bali cattle. Media Peternakan. 34:93-98. 
Hardjosubroto W. 2004. Alternatif kebijakan pengelolaan berkelanjutan sumberdaya genetik sapi potong lokal dalam sistem perbibitan ternak nasional. Wartazoa. 14:93-97.

Hartati, Sumadi, Subandriyo, Hartatik T. 2010. Keragaman morfologi dan diferensiasi genetik sapi Peranakan Ongole di peternakan rakyat. JITV. 15:72-80.

[KepMenTan] Keputusan Menteri Pertanian. 2012. Penetapan Rumpun Sapi Peranakan Ongole. http://bibit.ditjennak. pertanian.go.id

Kinsel ML, Marsh WE, Ruegg PL, Etherington WG. 1998. Risk factors for twinning in dairy cows. J Dairy Sci. 81:989-993.

Komisarek J, Dorynek Z. 2002. Genetic aspects of twinning in cattle. J Appl Genet. 43:55-68

Lasley JF. 1987. Genetics of livestock improvement. New Jersey (USA): Prentice Hall, Inc. Englewood Cliffs.

Maylinda S. 2010. Pengantar pemuliaan ternak. Malang (Indones): Universitas Brawijaya Press.

Nielen M, Schukken NYH, Scholl DT, Wilbrink HJ, Brand A. 1989. Twinning in dairy cattle: a study of risk factors and effects. Theriogenology. 32:845-862.
Noor RR. 2010. Genetika Ternak. 6th ed. Jakarta (Indones): PT Penebar Swadaya.

Prihandini PW, Hakim L, Nurgiartiningsih VMA. 2012. Seleksi Pejantan Berdasarkan Nilai Pemuliaan pada Sapi PO di Loka Penelitian Sapi Potong. Jurnal Ternak Tropika. 13:9-18.

Ryan DP, Boland MP. 1991. Frequency of twin births among Holstein-Friesian cows in a warm dry climate. Theriogenology. 36:1-10.

Steel RGD, Torrie JH. 1980. Principles and Procedures of Statistics. 2nd ed. New York (USA): McGraw-Hill.

Santos GCJ, Lopes FB, Marques EG, Silva MC, Cavalcante TV, Ferreira JL. 2012. Tendência genética para pesos padronizados aos 205, 365 e 550 dias de idade de bovinos Nelore na região norte do Brasil. Acta Scientiarum Animal Sciences. 34:97-101.

Silva RMD, Souza JCD, Silva LOCD, Silveira MVD, Freitas JAD, Marçal MF. 2013. Parâmetros e tendências genéticas para pesos de várias idades em bovinos Nelore. Rev Bras Saúde Prod Anim Salvador. 14:21-28.

Supartini N, Darmawan H. 2014. Profil genetik dan peternak sapi Peranakan Ongole sebagai strategi dasar pengembangan desa pusat bibit ternak. Buana Sains. 14:71-84. 